\title{
The Factors Influencing Technical College Students to Choose English-Learning Websites
}

\author{
Yi-Chien Lin, Ed. D. \\ Department of Tourism, Meiho University \\ 23, Pingkuang Rd., Neipu, Pingtung 91202, Taiwan, Republic of China \\ Mei-Miao Lin, Ed. D. \\ Department of Tourism, Meiho University \\ 23, Pingkuang Rd., Neipu, Pingtung 91202, Taiwan, Republic of China \\ Chiung-Li Li, Ed. D. (Corresponding author) \\ Department of Tourism, Meiho University \\ 23, Pingkuang Rd., Neipu, Pingtung 91202, Taiwan, Republic of China
}

Received: April 2, 2018 Accepted: April 26, 2018 Online published: May 13, 2018

doi:10.5296/ijhrs.v8i2.12929 URL: https://doi.org/10.5296/ijhrs.v8i2.12929

\begin{abstract}
The aim of the study is to examine the factors that influence technical college students to choose English-learning websites. The subjects were 165 students from a technical college in Southern Taiwan. The instrument was a questionnaire with three factors about choosing English-learning websites. One hundred sixty-five subjects completed a 10-minute questionnaire about English-learning websites in March 2017. The researchers collected the data from the questionnaire and analyzed the data using descriptive statistics and inferential statistics. The results revealed that most subjects stated that they liked to learn English, but went online to learn English less than one hour per week, and most subjects agreed that learning English online was helpful and English was important for their work and academy. The results also showed that most subjects believed English was related to a higher salary and future promotions, and they planned to improve their English. In addition, the results indicated that the subjects paid more attention to the practicality and convenience of an English-learning website than to the enjoyment of it. In this paper, the researchers draw
\end{abstract}


conclusions and discuss the teaching and research implications for the future.

Keywords: technical college, english learning website, practicality, convenience, enjoyment

\section{Introduction}

\subsection{Research Background and Motivation}

With the advance of mobile technology, mobile devices are more powerful nowadays with many useful tools to help people learn English. Internationalization is a trend, and to meet the needs in this scenario, possessing English abilities is important, especially for university students because they will form the next generation and possessing English ability can increase their competitiveness. In the past, learning English was limited to formal schooling. However, many people visit English-learning websites to learn English by computer, smart phone, or ipad, and so forth nowadays. That is, they apply Mobile-Assisted Language Learning (MALL) usually dealing with the use of mobile technology in language learning. In contrast to classroom learning, in MALL there is no need for learners to sit in a classroom or at a computer to get learning materials. In fact, MALL can be considered an ideal solution to language learning barriers with regard to time and place. Miangah \& Nezarat (2012) showed that the main characteristics of mobile learning (m-learning) are recognized as the potential for learning process to be personalized, spontaneous, informal and ubiquitous. Although learning through mobile phones may take longer time compared to classrooms, the learners feel a greater sense of freedom of time and place, so that they can take the advantage of spare time to learn a second language when and where they are. That is to say, more and more people learn English online because it is not restricted by time and space and it combines visual with auditory learning activities to attract learners. Ghulam et al. (2015) stated that research in cognitive psychology reveals that $83 \%$ of what is learned is from SIGHT, and $11 \%$ HEARING (Cuban, 2001); namely, the information obtained both visually and aurally explain $94 \%$ of total learning. Therefore, learning English online may be more and more popular, and how learners choose an English website is worth exploring.

The researchers have taught English in technical college for years and realized that promoting students' English skills is crucial to increase their future competitiveness. Based on Appendix $\mathrm{A}$ and $\mathrm{B}$, it is necessary for technical college students in Taiwan to promote their English if they want to enhance their global competitiveness. Introducing proper and popular English-learning websites is an effective method of providing students some English-learning resources. Moreover, it is possible for them to promote English proficiency by learning online.

In this study, the researchers would like to understand whether technical college students like to learn English, whether learning English is important for them. The researchers also wanted to examine how technical college students choose English-learning websites, and whether there were differences or relationships among technical college students in choosing English-learning websites. 


\section{Literature Review}

\subsection{Online Learning/E-learning}

Online learning has been employed since 1999 to help learners learn. Existing and emerging e-learning technologies are having intense, immediate, and disruptive transformative effects on education systems (Archer et al., 1999), and Anderson (2008) showed that online learning had been employed in educational environment, especially in the higher education and training sectors.

Whether online learning is better than traditional learning attracts some scholarly interest. A meta-analysis by Bernard et al. (2004) integrating research studies that compared learning from electronic distance education to learning from traditional classroom instruction yielded the achievement effect sizes and indicated no practical differences in learning between face-to-face and electronic distance learning. Miangah and Nezarat (2012) tried to identify the advantages and disadvantages derived from using mobile technologies for students as well as professionals. However, some distance learning courses were much more effective than classroom courses and vice versa.

Online learning has many advantages, such as access to low-anxiety environments (Chen, 2011) and up-to-date information (Liu et al., 2010), ability to learn at one's own pace (Kan, 2011), just-in-time learning, increased access, removal of time, place, and situational barriers, cost effectiveness, greater accountability, increased interaction, provision of future employment skills for students, and effective support for lifelong learning (Chen \& Li, 2010; Kanuka, 2008). That is, online learning could be a feasible alternative for learners outside school. Moreover, Tallent-Runnels et al. (2006) have stated that learning in an online environment can be as effective as that in traditional classrooms, and students' learning in the online environment is affected by the quality of online instruction.

In other words, online learning effectiveness depends on the quality of programs. Computers offer opportunities for unique engagement with simulations or with highly immersive environments that in some cases would be impossible to replicate outside a digital environment. That is, online learning has many advantages, but it is not perfect. More studies are required to explore online learning effectiveness or the characteristics of learning websites.

\subsection{English-Learning Website}

English online learning or English-learning websites have been discussed for years. Quite a few studies have highlighted the effectiveness of learning. For example, Chan and Liou (2005) indicated that learners made significant improvement in collocation immediately after the online practice but regressed later. Tsou et al. (2006) demonstrated successful usage of computer and online English learning and supported the significance and the education value of EFL online teaching and learning. By applying learning websites in EFL classrooms, the quality of teaching and learning can be improved, and students' enjoyment and success in EFL learning may increase. Yip and Kwan (2006) also found that the experimental group generally preferred online learning supplemented with digital educational games to traditional 
activity-based lessons and outperformed the control group statistically in the post-test. Miangah \& Nezarat (2012) also demonstrated the benefits of using cell phones in learning English as a second language. Shi (2016) stated that on-line English learning was individualized and it could enhance learning efficiency. English-learning websites seem to be an effective method of improving learners' learning effectiveness.

On the other hand, some studies focused on the evaluation of English-learning websites; for example, Liu et al. (2011) developed the evaluation guidelines of English learning websites based on web usability, learning materials, functionality of assisting language learning, technology integration, and learner preferences. Peterson (1998) focused on the factors influencing the design and evolution of virtual learning environment (VLE) sites and highlighted the importance of adopting a learner-centered design for virtual language learning environments. Jiang (2005) focused on an English audio-visual learning website's construction principles, system structure, and its application. Jeng et al. (2010) investigated the add-on effect of mobile applications in learning strategies, and essential characteristics of mobile learning were identified and discussed. Wu et al. (2012) showed that most studies of mobile learning focus on effectiveness, followed by mobile learning system design. Furthermore, cell phones and personal digital assistants (PDAs) are the most widely used devices for mobile learning (M-learning), but these may be substituted by emerging technologies. In addition, M-learning system design and system effectiveness were emphasized by the most highly cited articles.

Some studies focused on the factors influencing learners to choose English-learning websites, for example, Chang et al. (2012) showed that convenience is one of the features for mobile learning, and they would like to know whether it affects learners' attitude and intention of using mobile technology. Chang et al. found that perceived convenience, perceived ease of use and perceived usefulness were antecedent variables that connected with acceptance of English mobile learning, and had a significantly positive effect on attitude toward using websites. That is, the convenience of English-learning websites is crucial for learners.

In addition, some studies have found that the pleasure and enjoyment from English-learning websites increase learners' success, interests, and motivation (Chen \& Chung, 2008; Hsu, 2008; Sandberg et al., 2011; Shih, 2011; Tsou et al., 2006; Yang \& Chen, 2007; Zhang \& Zhao, 2007). That is to say, the enjoyment of English-learning websites is also quite important for learners.

Some studies have found that online games might be able to provide context-rich, cognitively engaging virtual environments for language learning, and online learning systems could obviously promote learners' English vocabulary acquisition (Chen \& Chung, 2008; Ranalli, 2008), college students' writing skills (Shih, 2011), listening ability (Kan, 2011), and oral skills (Chen, 2011). In other words, the practicality of English-learning websites is important for learners as well.

However, online learning is not perfect. Zhou et al. (2008) stated that although e-learning has been widely used at schools, some obvious disadvantages have been recognized. Many e-learning platforms are developed using existing technologies and compensate for the 
disadvantages of traditional teaching methods. Nevertheless, most of them are not flexible and efficient enough to support real world teaching and learning. Therefore, in this study, the researchers would like to examine the factors influencing technical college students' choice of English-learning websites.

\section{Methodology}

The study was conducted in two stages during the spring of 2017. In the first stage, a pilot study was conducted to assess the validity and reliability of the survey instrument (questionnaire about English-learning websites). The respondents in the pilot study included 91 undergraduate students enrolled in a technical college in Southern Taiwan.

The pilot study was conducted to gather respondents' feedback, uncover issues, hone the wording of the survey questions, check data collection results, and test the validity and reliability of the instrument. The questionnaire about English-learning websites can explain $71.71 \%$ of variance, which means the validity of it is quite good. The reliability analysis to test the consistency of the measuring instrument found that Cronbach's alpha value was .960 . According to Hair et al. (2010), the value significantly exceeds the recommended value of .70 and is considered good. That is, the questionnaire has high reliability.

Therefore, the researchers applied the pilot-studied questionnaire as the formal questionnaire. In the second stage, the focus of the study was to use the questionnaire on English-learning websites to examine technical college students' viewpoints in choosing English-learning websites.

\subsection{Subjects}

The study subjects were 165 technical college students from Southern Taiwan, all of them completed the questionnaire on English-learning websites in March 2017. According to the researchers' teaching experience, the subjects belong to a homogeneous group regarding their general English competence, because the subjects were from the classes the researchers are teaching.

\subsection{Research Instrument}

\section{Questionnaire on English-Learning Websites}

The researchers designed a self-administered structured questionnaire, which consisted of 15 items and was checked by three senior English teachers for expert validity, to gather the subjects' responses about English-learning websites generally. The 15 items were divided into three factors (enjoyment, convenience, practicality), each consisting of five items respectively. A Likert scale of $5=$ agree strongly, $4=$ agree, $3=$ neither agree nor disagree, $2=$ disagree, and 1 = disagree strongly was used to assess the respondents' viewpoints on English-learning websites. The five-point Likert scale was preferred to reduce the bias of Asian respondents (Truong, Yap, \& Ineson, 2012).

Data collected were analyzed using SPSS Version 17. Analysis of Variance (ANOVA) was used to test hypotheses concerning the variances of group responses on dependent variables 
from the practicality, enjoyment, and convenience of English-learning websites.

In the website questionnaire, convenience of websites refers to the factors making the websites convenient, accessible, and easy to use; practicality of websites refers to the factors making the websites useful, helpful, and practical to users; enjoyment of websites refers to the factors making users feel happy, joyful, and excited.

\section{Results and Discussion}

The 165 subjects completed the questionnaire about English-learning websites (Appendix C) in March 2017. The data collected from the questionnaire were used for further data analysis.

\section{Student Demographic Profile and Viewpoints about English-Learning Websites}

Table 1 shows the subjects' demographic profile and viewpoints on English-learning websites in the study. The characteristics and demographic data of the subjects were found to be as follows:

A significant majority of subjects $(76.4 \%)$ were female and $23.6 \%$ were male.

Most subjects (70.3\%) reported that they like to learn English.

A significant majority of subjects $(81.8 \%)$ reported that they spend less than one hour per week learning English online.

Many subjects (58.2\%) reported that they had English proficiency certificates.

A significant majority of subjects $(91.5 \%)$ reported that English is important for their future work.

A significant majority of subjects (87.5\%) reported that English is important for their schoolwork.

Most subjects (74.5\%) reported that learning English online is helpful.

A significant majority of subjects (87.9\%) reported that English is important for higher pay and future promotion.

A significant majority of subjects (89.1\%) reported that they wish to improve their English. 


\section{Macrothink}

International Journal of Human Resource Studies

ISSN 2162-3058 2018, Vol. 8, No. 2

Table 1. Demographic Characteristics and Reponses to English Learning of the Subjects $(n=$ 165)

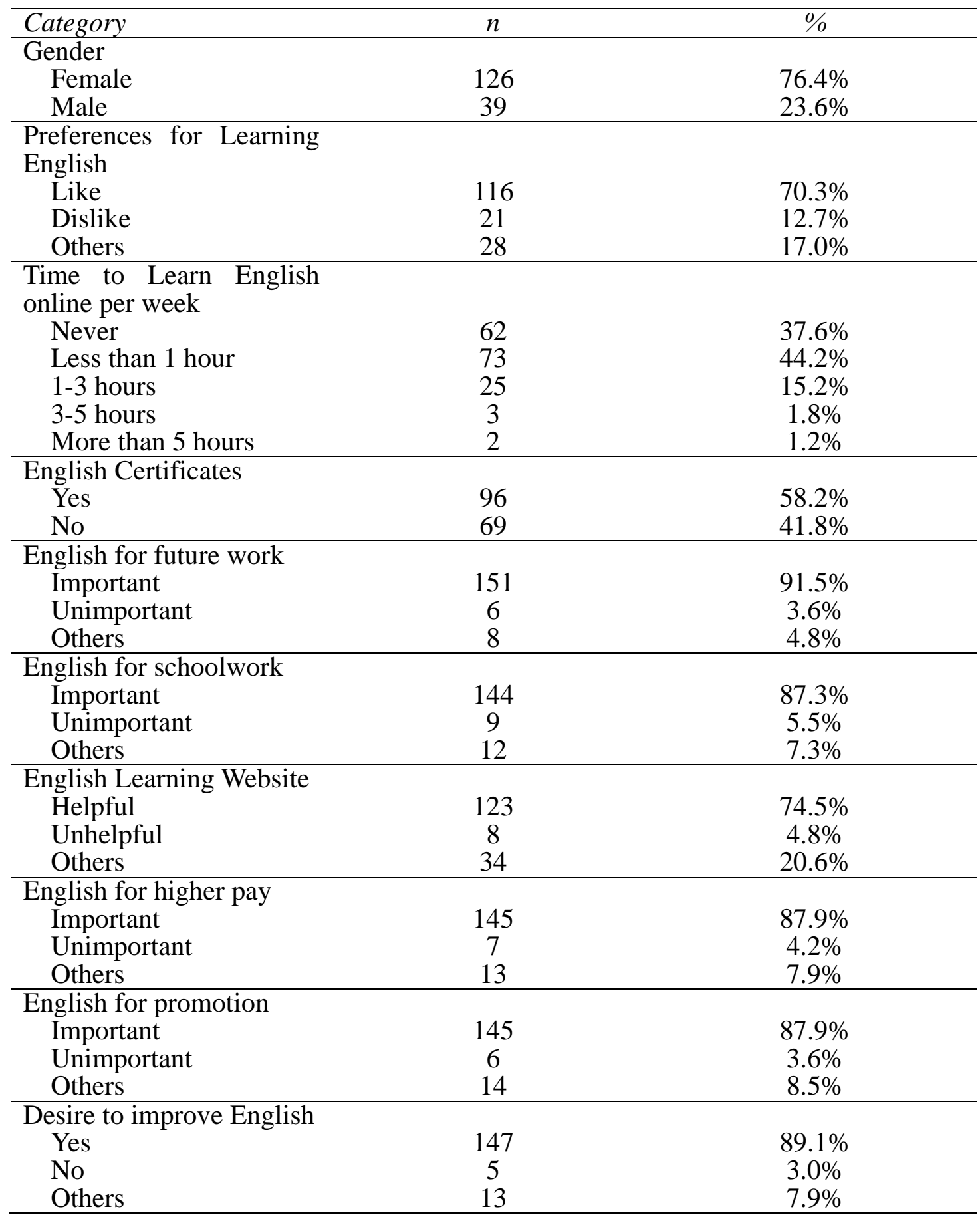

Table 2 shows that the mean for convenience was the highest (22.36), and the mean for entertainment was the lowest (21.51); the mode for convenience and practicality was the highest (25.00), and the mode for enjoyment was the lowest (20.00); the standard deviation $(S D)$ for enjoyment was the highest (2.95), and the $S D$ for convenience was the lowest (2.80). In other words, it seemed that most subjects would focus on the convenience and practicality of the website when they went online to learn English. The reason would be that the subjects still had pressure from schoolwork and future work. English is a required course in school, 
and job-hunters should possess enough English proficiency for higher-paying jobs. Naturally, the practicality of English-learning websites becomes important. In addition, getting information quickly and conveniently from English-learning websites makes users willing to use the websites again. Therefore, many users will take into account the convenience of English-learning websites. The results are consistent with the studies of Liu et al. (2010) and Chang et al. (2012).

Table 2. Summary of Questionnaire on English-Learning Websites $(n=165)$

\begin{tabular}{cccc}
\hline & Mean & Mode & SD \\
\hline Enjoyment & 21.51 & 20.00 & 2.95 \\
Convenience & 22.36 & 25.00 & 2.80 \\
Practicality & 22.10 & 25.00 & 2.93 \\
\hline
\end{tabular}

Table 3. One-sample t-test between Gender and English-Learning Websites $(n=165)$

\begin{tabular}{clcccc}
\hline & gender & number & M & SD & T-value \\
\hline Enjoyment & male & 39 & 21.23 & 3.38 & -.61 \\
& female & 126 & 21.60 & 2.82 & \\
Convenience & male & 39 & 21.90 & 3.34 & -1.03 \\
& female & 126 & 22.50 & 2.61 & \\
Practicality & male & 39 & 20.95 & 3.58 & $-2.86^{* *}$ \\
& female & 126 & 22.45 & 2.61 & \\
\hline
\end{tabular}

$* p<.05, * * p<.01, * * * p<.001$

As shown in Table 3, there were statistically significant differences between female and male group means as determined by the one-sample t-test about practicality of English-learning websites. In other words, female students thought the practicality of English-learning websites was more important than male respondents. The reason would be that female students usually care about their academic performance more than male ones in school; therefore, they will concern what the websites can promote their English capabilities and pay more attention to the practicality of English-learning websites.

Table 4. One-sample t-Test between Certificate and English-Learning Websites $(n=165)$

\begin{tabular}{cccccc}
\hline & Certificate & number & M & SD & T-value \\
\hline Enjoyment & Yes & 96 & 22.16 & 2.70 & 3.35 \\
& No & 69 & 20.61 & 3.08 & \\
Convenience & Yes & 96 & 22.86 & 2.44 & $2.80 *$ \\
& No & 69 & 21.65 & 3.12 & \\
Practicality & Yes & 96 & 22.79 & 2.56 & 3.61 \\
& No & 69 & 21.13 & 3.14 & \\
\hline
\end{tabular}

$* p<.05, * * p<.01, * * * p<.001$

As shown in Table 4, there were statistically significant differences between the with-certificate and the without-certificate group means as determined by the one-sample t-test in convenience of English-learning websites. In other words, subjects with English certificates about the convenience of English-learning websites were different from those without and more positive than those without. In general, those with English certificates already have enough English abilities; therefore, they will possibly focus on how to get 
information online more quickly and easily, and the convenience of using website will be more important for them.

Table 5. Anova between English-learning Preference and English-Learning Websites $(n=$ 165)

\begin{tabular}{cccccc}
\hline Item & & $S S$ & $D f$ & $F$ & Scheff \\
\hline Enjoyment & Between & 26.41 & 2 & 1.52 & \\
& Within & 1404.82 & 162 & & \\
Convenience & Total & 1431.24 & 164 & & \\
& Between & 12.23 & 2 & .78 & \\
& Within & 1273.67 & 162 & & \\
Practicality & Total & 1285.90 & 164 & & \\
& Between & 17.80 & 2 & 1.04 & \\
& Within & 1388.65 & 162 & & \\
& Total & 1406.45 & 164 & & \\
\hline
\end{tabular}

$* p<.05, * * p<.01, * * * p<.001$

Note: Group 1: The subjects like to learn English.

Group 2: The subjects do not like to learn English.

Group 3: The subjects do not know whether they like to learn English or not.

As shown in Table 5, regarding English-learning preference, there was no statistically significant difference between groups as determined by one-way ANOVA $(F(2,162)=1.52, p$ $=.221)$ on enjoyment, $(F(2,162)=.78, p=.461)$ on convenience, and $(F(2,162)=1.04, p$ $=.356)$ on practicality, respectively. That is, the subjects with different English-learning preference showed no differences in how they assessed the enjoyment, convenience, and practicality of English-learning websites. In fact, in the study, over $70 \%$ of the subjects like to learn English; therefore, it is not easy to tell the differences among groups.

Table 6. Anova between the Time Spending on English-Learning Websites and the Characteristics of English-Learning Websites $(n=165)$

\begin{tabular}{cccccc}
\hline Item & & $S S$ & $d f$ & $F$ & Scheff \\
\hline Enjoyment & Between & 33.53 & 4 & .96 & \\
& Within & 1397.71 & 160 & & \\
& Total & 1431.24 & 164 & & \\
Convenience & Between & 70.39 & 4 & 2.32 & \\
& Within & 1215.52 & 160 & & \\
& Total & 1285.90 & 164 & & \\
Practicality & Between & 43.52 & 4 & 1.28 \\
& Within & 1362.93 & 160 & & \\
& Total & 1406.45 & 164 & & \\
& & &
\end{tabular}

$* p<.05, * * p<.01, * * * p<.001$ 


\section{Macrothink}

International Journal of Human Resource Studies

ISSN 2162-3058 2018, Vol. 8, No. 2

Note: Group 1: The subjects never spent time on English-learning websites per week.

Group 2: The subjects spent less than one hour on English-learning websites per week.

Group 3: The subjects spent 1-3 hours on English-learning websites per week.

Group 4: The subjects spent 3-5 hours on English-learning websites per week.

Group 5: The subjects spent over 5 hours on English-learning websites per week.

As shown in Table 6, regarding time spent on English-learning websites, there was no statistically significant difference between groups as determined by one-way ANOVA $(F(2,162)=.96, p=.431)$ on enjoyment, $(F(2,162)=2.32, p=.060)$ on convenience, and $(F(2,162)=1.28, p=.281)$ on practicality, respectively. That is, despite differences in the amount of time that they spent on English-language websites, the subjects showed no significant differences in how they assessed the enjoyment, convenience, and practicality of those websites. In this study, over $80 \%$ of the subjects spent less than one hour learning English online weekly; therefore, it is not easy to tell the differences among groups.

Table 7. Anova between the Importance of English for Future Work and English-Learning Websites $(n=165)$

\begin{tabular}{cccccc}
\hline Item & & $S S$ & $d f$ & $F$ & Scheff \\
\hline Enjoyment & Between & 88.85 & 2 & $5.36^{* *}$ & $1>3$ \\
& Within & 1342.39 & 162 & & \\
& Total & 1431.24 & 164 & & $1>3$ \\
Convenience & Between & 65.52 & 2 & $4.35^{* *}$ & \\
& Within & 1220.38 & 162 & & $1>3$ \\
& Total & 1285.90 & 164 & & \\
\hline
\end{tabular}

${ }^{*} p<.05, * p<.01, * * * p<.001$

Note: Group 1: The subjects think English is important for their future work.

Group 2: The subjects do not think English is important for their future work.

Group 3: The subjects do not know whether English is important for their future work or not.

As shown in Table 7, regarding enjoyment, there was a statistically significant difference between groups as determined by one-way $\operatorname{ANOVA}(F(2,162)=5.36, p=.006)$, and group 1 was significantly different from group 3 . That is, the subjects with a positive opinion about English for their future work thought that the enjoyment of English-learning websites had more effect on them than those with an unclear opinion.

Regarding convenience, there was a statistically significant difference between groups as determined by one-way $\operatorname{ANOVA}(F(2,162)=4.35, p=.014)$; group 1 was significantly 
different from group 3. That is, the subjects with a positive opinion about English for their future work thought that the convenience of English-learning websites had more effect on them than those with an unclear opinion.

Regarding practicality, there was a statistically significant difference between groups as determined by one-way ANOVA $(F(2,162)=6.59, p=.002)$; group 1 was significantly different from group 3. That is, the subjects with a positive opinion about English for their future work thought that the practicality of English-learning websites had more effect on them than those with an unclear opinion.

The reason may be that subjects with a positive opinion about English for their future work would make good use of websites to promote their English. The enjoyment of websites makes them learn English happily; the convenience of websites makes them get information quickly, and the practicality of websites makes them obtain useful information. However, subjects with an uncertain opinion about English for their future work may doubt what the purpose of learning English is; therefore, they may have no desire or motivation to use English-learning websites.

Table 8. Anova between the Importance of English for Schoolwork and English-Learning Websites $(n=165)$

\begin{tabular}{cccccc}
\hline Item & & $S S$ & $d f$ & $F$ & Scheff \\
\hline Enjoyment & Between & 61.41 & 2 & $3.63^{* *}$ & $1>3$ \\
& Within & 1369.83 & 162 & & \\
& Total & 1431.24 & 164 & & $1>3$ \\
Convenience & Between & 85.41 & 2 & $5.76^{* *}$ & \\
& Within & 1200.49 & 162 & & $1>3$ \\
& Total & 1285.90 & 164 & & \\
& Between & 89.67 & 2 & $5.52^{* *}$ & \\
& Within & 1316.78 & 162 & & \\
& Total & 1406.45 & 164 & & \\
\hline
\end{tabular}

$* p<.05, * * p<.01, * * * p<.001$

Note: Group 1: The subjects think English is important for their schoolwork.

Group 2: The subjects do not think English is important for their schoolwork.

Group 3: The subjects do not know whether English is important for their schoolwork or not.

As shown in Table 8, regarding enjoyment, there was a statistically significant difference between groups as determined by one-way $\operatorname{ANOVA}(F(2,162)=3.63, p=.029)$, and group 1 was significantly different from group 3 . That is, subjects with a positive opinion about English for their schoolwork thought that the enjoyment of English-learning websites had more effect on them than those with an unclear opinion.

Regarding convenience, there was a statistically significant difference between groups as 
determined by one-way ANOVA $(F(2,162)=5.76, p=.004)$; group 1 was significantly different from group 3. That is, subjects with a positive opinion about English for their schoolwork thought that the convenience of English-learning websites had more effect on them than those with an unclear opinion.

Regarding practicality, there was a statistically significant difference between groups as determined by one-way ANOVA $(F(2,162)=5.52, p=.005)$; group 1 was significantly different from group 3. That is, subjects with a positive opinion about English for their schoolwork thought that the practicality of English-learning websites had more effect on them than those with an unclear opinion.

Generally speaking, subjects with a positive opinion about English for their schoolwork would make good use of websites to promote their English. The enjoyment of websites makes them learn English joyfully; the convenience of websites makes them get information fast, and the practicality of websites makes them obtain more knowledge. However, subjects with an uncertain opinion about English for their schoolwork may doubt what the goal of learning English is; therefore, they may have no desire or motivation to use English-learning websites.

Table 9. Anova between the Helpfulness of Learning English Online and English-Learning Websites $(n=165)$

\begin{tabular}{cccccc}
\hline Item & & $S S$ & $d f$ & $F$ & Scheff \\
\hline Enjoyment & Between & 119.08 & 2 & $7.35^{* *}$ & $1>3$ \\
& Within & 1312.16 & 162 & & \\
& Total & 1431.24 & 164 & & $1>3$ \\
Convenience & Between & 97.49 & 2 & $6.65^{* *}$ & \\
& Within & 1188.41 & 162 & & $1>3$ \\
& Total & 1285.90 & 164 & & \\
& Between & 62.55 & 2 & $3.77^{*}$ & \\
& Within & 1343.90 & 162 & & \\
\hline
\end{tabular}

$* p<.05, * * p<.01, * * * p<.001$

Note: Group 1: The subjects think learning English online is helpful.

Group 2: The subjects do not think learning English online is helpful.

Group 3: The subjects do not know whether learning English online is helpful or not.

As shown in Table 9, regarding enjoyment, there was a statistically significant difference between groups as determined by one-way $\operatorname{ANOVA}(F(2,162)=7.35, p=.001)$, and group 1 was significantly different from group 3 . That is, subjects with a positive opinion about learning English online thought that the enjoyment of English-learning websites had more effect on them than those with an unclear opinion.

Regarding convenience, there was a statistically significant difference between groups as 
determined by one-way ANOVA $(F(2,162)=6.65, p=.002)$; group 1 was significantly different from group 3. That is, subjects with a positive opinion about learning English online thought that the convenience of English-learning websites had more effect on them than those with an unclear opinion.

Regarding practicality, there was a statistically significant difference between groups as determined by one-way ANOVA $(F(2,162)=3.77, p=.025)$; group 1 was significantly different from group 3. That is, subjects with a positive opinion about learning English online thought that the practicality of English-learning websites had more effect on them than those with an unclear opinion.

Generally, the subjects with a positive opinion about learning English online would make good use of websites to promote their English. The enjoyment of websites makes them learn English interestingly; the convenience of websites makes them get information rapidly, and the practicality of websites makes them obtain helpful information. However, subjects with an unclear opinion about learning English online may doubt what the objective of learning English is; therefore, they may have no desire or motivation to use English-learning websites.

Table 10. ANOVA between the Importance of English for Higher Pay and English-Learning Websites $(n=165)$

\begin{tabular}{cccccc}
\hline Item & & $S S$ & $d f$ & $F$ & Scheff \\
\hline Enjoyment & Between & 80.71 & 2 & $4.84^{* *}$ & $1>3$ \\
& Within & 1350.53 & 162 & & \\
Convenience & Total & 1431.24 & 164 & & \\
& Between & 72.59 & 2 & $4.92^{* *}$ & $1>3$ \\
& Within & 1212.31 & 162 & & \\
Practicality & Total & 1285.90 & 164 & & $1>3$ \\
& Between & 87.12 & 2 & $5.35^{* *}$ & \\
& Within & 1319.34 & 162 & & \\
\hline
\end{tabular}

$* p<.05, * * p<.01, * * * p<.001$

Note: Group 1: The subjects think English is important for higher pay.

Group 2: The subjects do not think English is important for higher pay.

Group 3: The subjects do not know whether English is important for higher pay or not.

As shown in Table 10, regarding enjoyment, there was a statistically significant difference between groups as determined by one-way $\operatorname{ANOVA}(F(2,162)=4.84, p=.009)$, and group 1 was significantly different from group 3 . That is, subjects with a positive opinion about English for higher pay thought that the enjoyment of English-learning websites had more effect on them than those with an unclear opinion.

Regarding convenience, there was a statistically significant difference between groups as determined by one-way ANOVA $(F(2,162)=4.92, p=.008)$; group 1 was significantly 
different from group 3. That is, subjects with a positive opinion about English for higher pay thought that the convenience of English-learning websites had more effect on them than those with an unclear opinion.

Regarding practicality, there was a statistically significant difference between groups as determined by one-way ANOVA $(F(2,162)=5.35, p=.006)$; group 1 was significantly different from group 3. That is, subjects with a positive opinion about English for higher pay thought that the practicality of English-learning websites had more effect on them than those with an unclear opinion.

In general, subjects with a positive opinion about English for higher pay would make good use of websites to promote their English. The enjoyment of websites makes them learn English delightfully; the convenience of websites makes them get information quickly, and the practicality of websites makes them obtain practical information. However, subjects with an uncertain opinion about English for higher pay may doubt what the aim of learning English is; therefore, they may have no interest or motivation to use English-learning websites.

Table 11. Anova between the Importance of English for Promotion and English-Learning Websites $(n=165)$

\begin{tabular}{cccccc}
\hline Item & & $S S$ & $d f$ & $F$ & Scheff \\
\hline Enjoyment & Between & 78.82 & 2 & $4.72^{* * *}$ & $1>3$ \\
& Within & 1352.42 & 162 & & \\
& Total & 1431.24 & 164 & & $1>3$ \\
Convenience & Between & 132.79 & 2 & $9.33^{* * *}$ & \\
& Within & 1153.11 & 162 & & $1>3$ \\
& Total & 1285.90 & 164 & & \\
\hline & Between & 106.03 & 2 & $6.60^{* *}$ & \\
& Within & 1300.42 & 162 & & \\
& Total & 1406.45 & 164 & & \\
\hline
\end{tabular}

$* p<.05, * * p<.01, * * * p<.001$

Note: Group 1: The subjects think English is important for promotion.

Group 2: The subjects do not think English is important for promotion.

Group 3: The subjects do not know whether English is important for promotion or not.

As shown in Table 11, regarding enjoyment, there was a statistically significant difference between groups as determined by one-way $\operatorname{ANOVA}(F(2,162)=4.72, p=.010)$, and group 1 was significantly different from group 3 . That is, subjects with a positive opinion about English for promotion thought that the enjoyment of English-learning websites had more effect on them than those with an unclear opinion.

Regarding convenience, there was a statistically significant difference between groups as determined by one-way ANOVA $(F(2,162)=9.33, p=.000)$; group 1 was significantly 
different from group 3. That is, subjects with a positive opinion about English for promotion thought that the convenience of English-learning websites had more effect on them than those with an unclear opinion.

Regarding practicality, there was a statistically significant difference between groups as determined by one-way ANOVA $(F(2,162)=6.60, p=.002)$; group 1 was significantly different from group 3. That is, subjects with a positive opinion about English for promotion thought that the practicality of English-learning websites had more effect on them than those with an unclear opinion.

In general, the subjects with a positive opinion about English for promotion would make good use of websites to promote their English. The enjoyment of websites makes them learn English with joy; the convenience of websites makes them get information quickly, and the practicality of websites makes them obtain useful information. However, subjects with an uncertain opinion about English for promotion may doubt what the purpose of learning English is; therefore, they may have no desire or intention to use English-learning websites.

Table 12. Anova between the Desire to Learn English and English-Learning Websites $(n=$ 165)

\begin{tabular}{cccccc}
\hline Item & & $S S$ & $d f$ & $F$ & Scheff \\
\hline Enjoyment & Between & 60.54 & 2 & $3.58^{* *}$ & $1>3$ \\
& Within & 1370.70 & 162 & & \\
& Total & 1431.24 & 164 & & \\
Convenience & Between & 38.64 & 2 & 2.51 & \\
& Within & 1247.26 & 162 & & \\
& Total & 1285.90 & 164 & & \\
Practicality & Between & 62.08 & 2 & $3.74 *$ & \\
& Within & 1344.37 & 162 & & \\
& Total & 1406.45 & 164 & & \\
\hline
\end{tabular}

$* p<.05, * * p<.01, * * * p<.001$

Note: Group 1: The subjects would like to improve their English.

Group 2: The subjects would not like to improve their English.

Group 3: The subjects do not know whether they want to improve their English or not.

As shown in Table 12, regarding enjoyment, there was a statistically significant difference between groups as determined by one-way ANOVA $(F(2,162)=3.58, p=.030)$, and group 1 was significantly different from group 3 . That is, subjects with a positive opinion about improving English thought that the enjoyment of English-learning websites had more effect on them than those with an unclear opinion.

Regarding convenience, there was no statistically significant difference between groups as determined by one-way ANOVA $(F(2,162)=2.51, p=.084)$; that is, subjects with different opinions about improving English thought that the convenience of English-learning websites 
had similar effect on them.

Regarding practicality, there was a statistically significant difference between groups as determined by one-way ANOVA $(F(2,162)=3.74, p=.026)$; group 1 was significantly different from group 3. That is, subjects with a positive opinion about improving English thought that the practicality of English-learning websites had more effect on them than those with an unclear opinion.

In general, subjects having motivation to improve English would make good use of websites to promote their English. The enjoyment of websites makes them have more motivation to learn English. Because of high motivation, those people would do their best to use English-learning websites instead of focusing on the convenience of websites. Moreover, the practicality of websites makes them obtain more practical information. On the other hand, subjects with an uncertain opinion about improving their English may doubt what the purpose of learning English is; therefore, they may have no willingness or motivation to use English-learning websites.

\section{Conclusion}

In this study, most subjects reported that they liked to learn English and believed that English was important for their schoolwork, job, higher pay, and future promotion. Most subjects wished to improve their English and agreed that English online learning was helpful; however, they spent less than one hour per week to learn English online.

Regarding the English website questionnaire, female students' opinions about the practicality of English-learning websites were more positive than male students'. The opinions of subjects with English certificates about the convenience of English-learning websites were more positive than those without.

There was no significant difference in the enjoyment, convenience, and practicality of English-learning websites among the subjects with different preferences for English learning and the subjects with different time spent on English-learning websites.

The subjects with a positive opinion about English for their schoolwork, future work, higher pay, and promotion thought that the enjoyment, convenience, and practicality of English-learning websites had more effect on them than those with an unclear opinion.

The subjects with a positive opinion about improving English thought that the enjoyment and practicality of English-learning websites had more effect on them than those with an unclear opinion. However, the subjects with different opinions about improving English thought that the convenience of English-learning websites had similar effects on them.

\section{Implications, Limitations, and Future Research}

\subsection{Implications}

Based on the results, teachers could recommend some well-designed English-learning websites to learners and instruct them how to use the websites in their free time. Furthermore, teachers could encourage students to use English-learning websites after classes regularly to 
develop a habit to learn English and gradually increase learning effectiveness. Teachers could also focus on different functions and characteristics of English-learning websites according to gender, English level, and learning purposes of learners. Teachers could invite some successful English on-line learners to share their learning experiences to make students have learning models to follow.

\subsection{Limitations and Recommendations for Future Research}

Low generalizability is a limitation of the study because the study used a convenience sampling method by choosing students from the technical college the researchers teach at, which makes generalizing the findings in the study a challenge. To address the limitations of the study, the researchers can examine other technical college students in English online learning in the future research. What is more, this study should be repeated in the future with a larger sample size to confirm the relationships between English-learning websites and subjects' backgrounds.

\section{References}

Anderson, T. (2008). The theory and practice of online learning. Athabasca: Athabasca University Press.

Archer, J. (1999). Assessment of the reliability of the conflict tactics scales: A meta-analytic review. Journal of Interpersonal Violence, 14(12), 1263-1289. https://doi.org/10.1177/088626099014012003

Bernard, R. M., Abrami, P. C., Lou, Y., Borokhovski, E., Wade, A., Wozney, L., ... \& Huang, B. (2004). How does distance education compare with classroom instruction? A meta-analysis of the empirical literature. Review of educational research, 74(3), 379-439. https://doi.org/10.3102/00346543074003379

Chan, T. P., \& Liou, H. C. (2005). Effects of web-based concordancing instruction on EFL students' learning of verb-noun collocations. Computer Assisted Language Learning, 18(3), 231-251. https://doi.org/10.1080/09588220500185769

Chang, C. C., Yan, C. F., \& Tseng, J. S. (2012). Perceived convenience in an extended technology acceptance model: Mobile technology and English learning for college students. Australasian Journal of Educational Technology, 28(5), 809-826. https://doi.org/10.14742/ajet.818

Chen, C. M., \& Chung, C. J. (2008). Personalized mobile English vocabulary learning system based on item response theory and learning memory cycle. Computers \& Education, 51(2), 624-645. https://doi.org/10.1016/j.compedu.2007.06.011

Chen, C. M., \& Li, Y. L. (2010). Personalized context-aware ubiquitous learning system for supporting effective English vocabulary learning. Interactive Learning Environments, 18(4), 341-364. https://doi.org/10.1080/10494820802602329

Chen, H. H. J. (2011). Developing and evaluating an oral skills training website supported by automatic speech recognition technology. ReCALL, 23(1), 59-78. 
https://doi.org/10.1017/S0958344010000285

Clark, R. C., \& Mayer, R. E. (2016). E-learning and the science of instruction: Proven guidelines for consumers and designers of multimedia learning. Hoboken: John Wiley \& Sons. https://doi.org/10.1002/9781119239086

Cuban, L. (2001). Computers in the Classroom. Cambridge, M.A. Harvard University Press. Retrieved from http://www.webpages. uidaho.edu/mbolin/akerele-afolable.htm

Ghulam S., Khuram S. H., Naqvi H., \& Nadeem, I. (2015). Impact of Visual Aids in Enhancing the Learning Process Case Research: District Dera Ghazi Khan. Journal of Education and Practice, 19(6), 226-233.

Hair, J. F., Black, W. C., Babin, B. J., \& Anderson, R. E. (2010). Multivariate data analysis ( $7^{\text {th }}$ ed.). Upper Saddle River: Prentice Hall.

Hsu, M. H. (2008). A personalized English learning recommender system for ESL students. Expert Systems with Applications, 34(1), 683-688. https://doi.org/10.1016/j.eswa.2006.10.004

Jeng, Y. L., Wu, T. T., Huang, Y. M., Tan, Q., \& Yang, S. J. (2010). The add-on impact of mobile applications in learning strategies: A review study. Educational Technology \& Society, 13(3), 3-11.

Jiang, L. P. (2005). Construction and Application of an English Visual-Audio Learning Website. Media in Foreign Language Instruction, 5, 016.

Kan, S. O. (2011). Critique of a Language-Learning Website. Online Submission, 8(5), 675-681.

Kanuka, H. (2008). Understanding E-Learning Technologies-in-Practice through Philosophies-in-Practice. In T, Anderson (Ed.) The theory and practice of online learning, Athabasca: Athabasca University Press. (p.92)

Li, C. L. (2017). Technical College Students' Hospitality-Related English Vocabulary Learning Motivation and Achievement. International Journal of Innovative Research and Knowledge, 8(2), 14-33.

Li, C. L. (2017). The Study of Technical University Students' Tourism English Vocabulary Learning Motivation and Achievement. International Journal of Development Research, 7(3), 12116-12123.

Li, C. L., Chen, Y. C., \& Li, H. Y. (2018). Technical College Students' ARCS Learning Motivation on Hospitality English Vocabulary. International Journal of Human Resource Studies, 8(1), 189-207. https://doi.org/10.5296/ijhrs.v8i1.12370

Liu, G. Z., Liu, Z. H., \& Hwang, G. J. (2011). Developing multi-dimensional evaluation criteria for English learning websites with university students and professors. Computers \& Education, 56(1), 65-79. https://doi.org/10.1016/j.compedu.2010.08.019

Liu, I. F., Chen, M. C., Sun, Y. S., Wible, D., \& Kuo, C. H. (2010). Extending the TAM 
model to explore the factors that affect Intention to Use an Online Learning Community. Computers \& education, 54(2), 600-610. https://doi.org/10.1016/j.compedu.2009.09.009

Miangah, T. M., \& Nezarat, A. (2012). Mobile-assisted language learning. International

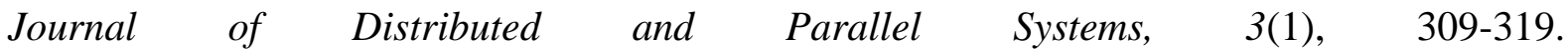
https://doi.org/10.5121/ijdps.2012.3126

Peterson, M. (1998). The virtual learning environment: The design of a website for language learning. Computer Assisted Language Learning, 11(4), 349-361. https://doi.org/10.1076/call.11.4.349.5669

Ranalli, J. (2008). Learning English with The Sims: exploiting authentic computer simulation games for L2 learning. Computer Assisted Language Learning, 21(5), 441-455. https://doi.org/10.1080/09588220802447859

Sandberg, J., Maris, M., \& de Geus, K. (2011). Mobile English learning: An evidence-based study with fifth graders. Computers \& Education, 57(1), 1334-1347. https://doi.org/10.1016/j.compedu.2011.01.015

Shi, S. (2016). Computer English Teaching Model Based on Multimedia Platform. IJET, 11(8), 59-64. https://doi.org/10.3991/ijet.v11i08.6050

Shih, R. C. (2011). Can Web 2.0 technology assist college students in learning English writing? Integrating Facebook and peer assessment with blended learning. Australasian Journal of Educational Technology, 27(5), 829-845. https://doi.org/10.14742/ajet.934

Survey Report of English Requirement for Employees in Top 1000 Taiwan Industries. http://www.toeic.com.tw/img_report/2012report.pdf

Tallent, R. M. K., Thomas, J., Lan, W., Cooper, S., Ahern, T., Shaw, S., \& Lieu, X. (2006). Teaching courses online: A review of the research. Review of Educational Research, 76(1), 93-135. https://doi.org/10.3102/00346543076001093

TOEIC Score Report for Test-takers in Taiwan in 2016 http://www.toeic.com.tw/file/17054017.pdf

Truong, T. T., Yap, M. H., \& Ineson, E. M. (2012). Potential Vietnamese consumers' perceptions of organic foods. British Food Journal, 114(4), 529-543. https://doi.org/10.1108/00070701211219540

Tsou, W., Wang, W., \& Tzeng, Y. (2006). Applying a multimedia storytelling website in foreign language learning. Computers \& Education, 47(1), 17-28. https://doi.org/10.1016/j.compedu.2004.08.013

Wu, W. H., Wu, Y. C. J., Chen, C. Y., Kao, H. Y., Lin, C. H., \& Huang, S. H. (2012). Review of trends from mobile learning studies: A meta-analysis. Computers \& Education, 59(2), 817-827. https://doi.org/10.1016/j.compedu.2012.03.016

Yang, C. H., \& Chen, Y. (2007). Constructing an English learning website for Taiwanese college students: An example in Chungchou Institute of Technology. The Proceedings of 
Internet Resources and English Teaching Conference, 66-81.

Yang, S. C., \& Chen, Y. J. (2007). Technology-enhanced language learning: A case study. Computers in Human Behavior, 23(1), 860-879. https://doi.org/10.1016/j.chb.2006.02.015

Yip, F. W., \& Kwan, A. C. (2006). Online vocabulary games as a tool for teaching and learning English vocabulary. Educational media international, 43(3), 233-249. https://doi.org/10.1080/09523980600641445

Zhang, F. K., \& Zhao, T. (2007). Teaching College English Listening Based on English Audio-visual Learning Website. Cafe Computer-Assisted Foreign Language Education, 1, 006.

Zhou, D., Zhang, Z., Zhong, S., \& Xie, P. (2008). The design of software architecture for e-learning platforms. Technologies for E-Learning and Digital Entertainment, 32-40. https://doi.org/10.1007/978-3-540-69736-7_4

\section{Appendix A}

TOEIC Scores of General University and Technical College Test-Takers in 2015 and 2016 and TOEIC Requirement for Workplaces in Taiwan in 2015

\begin{tabular}{c|c|c|c}
\hline $\begin{array}{c}\text { General University } \\
\text { TOEIC test-takers' } \\
\text { Score in } 2015\end{array}$ & $\begin{array}{c}\text { General University } \\
\text { TOEIC test-takers' } \\
\text { Score in 2016 }\end{array}$ & $\begin{array}{c}\text { Technical college } \\
\text { TOEIC test-takers' } \\
\text { Score in 2015 }\end{array}$ & $\begin{array}{c}\text { Technical college } \\
\text { TOEIC test-takers' } \\
\text { Score in 2016 }\end{array}$ \\
\hline 561 & 565 & 413 & 413 \\
\hline \multicolumn{2}{c}{ The Threshold of TOEIC for Recruitment in Different Industries in Taiwan in 2015 } \\
\hline Manufacturing & \multicolumn{3}{c}{522.2} \\
\hline Service & 564.7 \\
\hline Financial & 652.5 \\
\hline
\end{tabular}

Note: adapted from Li (2017), Li (2017) \& Li et al. (2018)

\section{Appendix B}

TOEIC Required Scores in Different Industries in Taiwan in 2016

\begin{tabular}{|c|c|c|c|}
\hline Industry & Listening scores & Reading scores & Total scores \\
\hline diplomatic affairs & 343 & 288 & 631 \\
\hline trade & 334 & 277 & 611 \\
\hline \multicolumn{4}{|c|}{---} \\
\hline $\begin{array}{l}\text { hotel/travel/ } \\
\text { entertainment/hospitality/ } \\
\text { restaurant }\end{array}$ & 262 & 194 & 455 \\
\hline
\end{tabular}

Note: adapted from Li (2017), Li (2017) \& Li et al. (2018)

\section{Appendix C}

\section{Part I}

1. You are $\square$ male $\square$ female

2. Do you like to learn English? $\square$ Yes $\square$ No $\quad \square$ Unknown 


\section{Macrothink}

International Journal of Human Resource Studies

ISSN 2162-3058 2018, Vol. 8, No. 2

3. How long do you learn English online every week? $\square 0$ hour $\quad \square$ Less than 1hour $\square 1-3$ hours $\quad \square 3-5$ hours $\square$ More than 5 hours

4. Do you have any English certificate? (e.g., GEPT $\cdot$ TOEIC $\cdot$ CESPT ...) $\quad$ Yes $\quad \square$ No

5. Do you think English is important for you to find a job in the future? $\square$ Yes $\square$ No 口Unknown

6. Do you think English is important for your studies? $\square$ Yes $\quad \square$ No $\quad \square$ Unknown

7. Do you think English-learning websites are useful? $\square$ Yes $\square$ No $\quad \square$ Unknown

8. Do you think English is important for you to get higher pay in the future? $\square$ Yes $\square$ No 口Unknown

9. Do you think English is important for promotion in the future? $\square$ Yes $\quad \square$ No 口Unknown

10. Do you wish to improve your English? $\square$ Yes $\quad \square$ No $\quad \square$ Unknown

\section{Part II}

\begin{tabular}{|c|c|c|c|c|c|}
\hline English-Learning Websites Questionnaire & $\begin{array}{l}\text { A } \\
\text { S }\end{array}$ & A & $\mathrm{N}$ & $\mathrm{D}$ & $\begin{array}{l}\mathrm{D} \\
\mathrm{S}\end{array}$ \\
\hline 1. The layout of website is important. & 5 & 4 & 3 & 2 & 1 \\
\hline 2. The color setup of website is important. & 5 & 4 & 3 & 2 & 1 \\
\hline 3. The typeface of website is important. & 5 & 4 & 3 & 2 & 1 \\
\hline 4. The brightness of website is important. & 5 & 4 & 3 & 2 & 1 \\
\hline 5. The audio \& video of website is important. & 5 & 4 & 3 & 2 & 1 \\
\hline 6. The website being easy to use is important. & 5 & 4 & 3 & 2 & 1 \\
\hline 7. Having the navigation of website easy to use is important. & 5 & 4 & 3 & 2 & 1 \\
\hline 8. The website being convenient to use is important. & 5 & 4 & 3 & 2 & 1 \\
\hline $\begin{array}{l}\text { 9. Being able to search the website easily for information is } \\
\text { important. }\end{array}$ & 5 & 4 & 3 & 2 & 1 \\
\hline 10. Having clear information on the website is important. & 3 & 4 & 3 & 2 & \\
\hline 11. Having rich content on a website is important. & 5 & 4 & 3 & 2 & 1 \\
\hline 12. Having practical content on a website is important. & 5 & 4 & 3 & 2 & 1 \\
\hline 13. The website providing information for exams is important & 5 & 4 & 3 & 2 & 1 \\
\hline 14. The website containing current events is important. & 5 & 4 & 3 & 2 & 1 \\
\hline $15 . \mathrm{T}$ & 5 & 1 & & & \\
\hline
\end{tabular}

Note: AS: agree strongly $\mathrm{A}$ : agree $\mathrm{N}$ : neither agree nor disagree $\mathrm{D}$ : disagree $\mathrm{DS}$ : disagree strongly

Items 1-5: Enjoyment; Items 6-10: Convenience; Items 11-15: Practicality

\section{Copyright Disclaimer}

Copyright for this article is retained by the author(s), with first publication rights granted to the journal.

This is an open-access article distributed under the terms and conditions of the Creative Commons Attribution license (http://creativecommons.org/licenses/by/4.0/). 